\title{
Are "the best" foreign subsidiaries cooperating for innovation with local partners? The case of an intermediate country
}

\author{
Antonio García Sánchez \\ Lecturer of Applied Economics. \\ Departamento de Economía e Historia Económica \\ Facultad de Ciencias Económicas y Empresariales, \\ Universidad de Sevilla \\ Avenida Ramón y Cajal, 1 \\ 41018 Sevilla, Spain \\ José Molero \\ Professor of Applied Economics (Chair). \\ Instituto de Estudios de la Innovación. \\ Parque Científico de Madrid. \\ C/ Faraday, 7. \\ Campus de Cantoblanco, \\ 28049 Madrid, Spain \\ Ruth Rama \\ Research Professor \\ IEGD-CSIC \\ Albasanz, 26-28 \\ 28037 Madrid, Spain
}

*Corresponding author. E-mail: ruth.rama@cchs.csic.es. Phone: 3491 6022402. Fax: 34916022971

Funding. Ruth Rama gratefully acknowledges that this work was supported by projects ECO2013-41317-R

(Spanish Ministry of Economy and Competitiveness) and P10-SEJ05827 (Junta de Andalucía).

Acknowledgements. The authors thank the referees for their useful comments and suggestions.

This is a pre-copyedited, author-produced version of an article accepted for publication in Science and Public Policy following peer review. The version of record García Sánchez, A., Molero, J., \& Rama, R. (2016). Are "the best" multinationals cooperating locally for innovation? The case of an intermediate country. Science \& Public Policy (SPP), 43(4), 532-545.DOI: https://doi.org/10.1093/scipol/scv057 is available online at: https://academic.oup.com/spp/article/43/4/532/2514633 
Abstract: We analyse, over 2004-2008, a sample of firms representative of Spanish manufacturing industry, in order to understand the relationship between foreign status and local cooperation for innovation. More specifically, we focus on foreign subsidiaries displaying innovation intensity, newness of technology or ability to build complex networks with local innovators. Foreign status increases the probability of local cooperation for innovation. However, foreign subsidiaries displaying the abovementioned characteristics are not necessarily more prone to cooperate locally for innovation than similar affiliated domestic firms. FS are able to build complex cooperative networks with local partners but multi cooperative FS are not especially interested in fast changing sectors. In contrast to cooperative affiliated domestic firms, the distribution of cooperative FS tends to be even across sectors and this is confirmed for advanced FS. This suggests that FS look for general capabilities in local partnerships, rather than for specific expertise. The strategies of domestic affiliated firms seem to influence the relationship between foreign status and local cooperation for innovation.

Key words: foreign subsidiaries, multinational enterprises, cooperation for innovation, networks of innovators

JEL: F023, O030 


\section{INTRODUCTION.}

Policy makers often wish to attract foreign direct investment (hereafter, FDI) because they see it as a potential source of skills and new knowledge for the hostcountry. Although these expectations are sometimes too optimistic, competition to attract research and development (hereafter, R\&D) intensive FDI has increased in recent years (Guimón 2011). According to the empirical literature, technology transfers are facilitated when foreign subsidiaries (hereafter, FS) build linkages with local partners (UNCTAD 2001). After reviewing European Union (EU) policies aimed at benefiting from the globalization of corporate $R \& D$, one study concluded that more policy intervention focused on linkage facilitation is needed (Guimón 2011). One such linkage is cooperation for innovation with local partners ${ }^{1}$.

However, a number of circumstances, such as high transaction costs, may limit the local embeddedness of FS and, hence, their potential for transferring knowledge to the domestic economy. FS may not be able to build local linkages similar to those of domestic firms. A literature mostly based on the Community Innovation Survey (CIS) of the EU has investigated whether FS are more prone to engage in cooperation for innovation (or, in local cooperation for innovation) than domestic firms. Results are not conclusive. The impact of foreign ownership on local cooperation for innovation seems to change by country and sector (Ebersberger et al. 2011; Holl and Rama 2014 ; Knell and Srholec 2006; Molero and Heijs 2002).

This literature has provided important insights that are crucial for the formulation of informed policies. However, some aspects of the relationship between foreign status and local cooperation for innovation probably deserve further analysis; first, a specific focus on the patterns of local cooperation for innovation of those FS that may potentially make a greater technological contribution to the host country. Secondly, with some exceptions (see, for instance, Schmidt and Sofka 2009), previous studies have assumed that the impact of foreign status on local cooperation is almost exclusively attributable to the strategies of FS. It may be useful to investigate, however, whether the cooperative strategies of domestic firms may indirectly affect the relationship between foreign ownership and local cooperation for innovation. Finally, most previous studies analyse highly industrialised countries. In our view, their results need to be complemented with studies on other countries in order to integrate a complete picture of these cooperative activities. However, with few exceptions (see, for instance, Holl

\footnotetext{
${ }^{1}$ Also referred to in the literature and in this article as R\&D cooperation or as collaboration for innovation.
} 
and Rama 2014; Srholec 2009), in depth analyses on those countries are rare. We focus on Spain as a paradigmatic case of an intermediate country. As in other cases, Spain shows a historical imbalance between its technological development and its economic development. For instance, one study classifies Spain among high income, low R\&D European countries (Ebersberger et al 2011). Furthermore, Spain's technological development is also imbalanced (we return to this question below). These types of countries may be far-away from the technological frontier in some sectors, and close to it in others (e.g. in traditional industries). Our point of departure is the assumption that, in such types of economies, the relationship between foreign subsidiaries and the national innovation system (hereafter, NIS) shows significant peculiarities that need to be understood.

This article attempts to contribute to this literature. Our ultimate objective is to understand whether foreign manufacturing subsidiaries are likely to make a contribution to domestic innovative capabilities. More specifically, we select for analysis FS displaying above average intensity of innovation, newness of technology or the capability to build complex networks of innovators (definitions below). Although other criteria are certainly valid, FS showing some of these characteristics are considered here as "the best" FS from the point of view of the host country. We address four questions. The first is whether innovation intensive FS are prone to cooperate locally for innovation. We are interested in these companies because low technology FDI may contribute little in terms of new knowledge and, instead, crowd out domestic firms (Buckley et al. 2007). FS operating in manufacturing sectors where technological change is rapid worldwide are prone to cooperate locally for innovation. The presence, in those sectors, of FS willing to provide opportunities for cooperation for innovation to local partners may help the host country to catch up with rapidly changing technology. Different technologies do not have the same "value" for host countries and these companies may, in theory, bring state-of-the-art technology not yet available locally. In a country such as Spain, the need for transfers of technology from FDI is probably less pressing in slow changing sectors. In these sectors, the host-country is probably closer to the technological frontier, given the slow rhythm of international technological upgrading, than it is in the case of fast changing sectors. The third question is whether FS operating in fast changing sectors are significantly more prone to cooperate locally for innovation than FS operating in slow changing sectors. We know very little about sectoral drivers of inward R\&D flows (Alkemade et al. 2015) and virtually nothing about the preferences of FS concerning collaborative arrangements with local innovators across sectors. However, these sectoral aspects may have implications regarding 
national policies towards FDI in R\&D. The fourth question is whether FS are able to build complex cooperative networks with local partners; and in which sectors (definition below). Complex networks seem especially valuable from the point of view of the host country since they combine knowledge coming from different local sources (e.g. universities, research centres, suppliers), as well as from the MNE. Therefore, they display a substantial potential to generate new ideas (see, for instance, Faems et al. 2005).

Therefore, we explore whether FS displaying above average intensity of innovation, newness of technology and the ability to build complex networks of innovators tend to be engaged in local cooperation for innovation. In doing so, we use a sample of firms that is statistically representative of the Spanish manufacturing industry. Local R\&D cooperative behaviour is compared in FS and domestic firms affiliated to Spanish entrepreneurial groups; additional comparisons are made with a sub-sample of innovation intensive companies. Though our study provides some hints about the relative merits of domestic $R \& D$ and foreign $R \& D$, this is not our central objective. Rather, we use affiliated domestic firms as a control group in order to understand the specificities of FS. As stated, Spain is one of the most important recipients of inward FDI in the EU (UNCTAD 2012). FS account for $39.5 \%$ of national manufacturing R\&D, with substantial differences between sectors (for instance, only $15.5 \%$ in food, beverages and tobacco, and $86.5 \%$ in office, accounting and computing machinery) ${ }^{2}$. Some emerging economies and other peripheral European countries may be in a similar situation. Being substantial receivers of FDI, they may also expect to link their NIS to international flows of knowledge via FS; hence, the interest of an in depth analysis of the Spanish case.

Section 2 reviews the literature that informed our research, Section 3, presents the data and variables used in the quantitative analyses, and Section 4, the results. Section 5 contains the discussion. Section 6 concludes.

\section{LITERATURE REVIEW AND RESEARCH QUESTIONS}

\subsection{Foreign subsidiaries and technology upgrading of host-countries.}

\footnotetext{
${ }^{2}$ OECD Globalisation statistics http://stats.oecd.org/index.aspx, as of January 2014. Data for 2007, last year available.
} 
Although most of the literature assumes that FS are able to make substantial contributions to the technology upgrading of host-countries, this view seems at times unjustified. According to a review of the literature (Rama 2009), there has been concern that FS could siphon off a host country's accumulated knowledge, liquidate its independent science and technology base, access publicly-funded R\&D and bring in the wrong technology. There has also been concern in the opposite direction, that FS would not conduct R\&D in host countries and would bring only their low value-added activities. A certain number of MNEs are not especially innovative or only a few of their "superstar" subsidiaries are, usually located in highly industrialised countries. Certain authors have, at least theoretically, posed the question of "multinationals without advantages" (Fosfuri and Motta 1999). In contrast, in other countries, FS perform a substantial share of total innovation and some studies point to the risks involved in the concentration of technology in the hands of a few firms (Archibugi and Petrobelli 2003).

The idea of a transfer of technology from the FS to the local economy has sometimes been contested (Veugelers and Cassiman 2004). FDI may even have disruptive effects on the NIS since FS could displace innovative domestic firms (UNCTAD 2005). More specifically, concerning cooperation for innovation FS seem to behave differently in countries with different technological level. In host countries that are not technology leaders, the risk of branch plant syndrome is greater (Ebersberger et al. 2011; Srholec 2009). Forms of organisation adopted by branch plants do not necessarily imply increased local embeddedness or better prospects for local development (Phelps 1993). The discussion specifically points to the importance of understanding the local cooperative behaviour of FS enjoying desirable characteristics.

\subsection{Foreign ownership and local cooperation for innovation.}

MNEs tend to increasingly innovate abroad to adapt their products to national tastes and regulations, learn from foreign lead markets or lead customers, access the NIS, or use publicly-funded R\&D available in the host-country (Dunning and Lundan 2009).

Although this seems to predict that FS will be prone to engage in local cooperation for innovation in their host-countries, the empirical literature is not conclusive in this regard. Srholec (2009), studying 12 European countries, finds that FS tend to cooperate for innovation with external partners, especially those located abroad (not in the host country). Working with data for the Czech manufacturing sector, Knell and Srholec (2006) observe that foreign status is a predictor of not only less local cooperation for innovation, but also reduced in-house R\&D. A study on 22 
European countries finds that it is positively associated with international R\&D collaboration and negatively associated with domestic R\&D collaboration (Ebersberger et al. 2011). The authors conclude that the risk of branch plant syndrome is empirically supported, especially in those European countries that are not technology leaders (as is the case of Spain). Another study on European countries confirms this view (Srholec 2009). In spite of Spain not being a technology leader, a study on service and manufacturing companies finds that FS operating there tend, nevertheless, to engage in local cooperation for innovation to a greater extent than affiliated or unaffiliated domestic firms (Holl and Rama 2014 ).

The FS most likely to launch networks with local innovators seem to be those involved in local R\&D. R\&D expenditures approach the absorptive capacity of firms and, therefore, their capacity to profit from externalities (Cohen and Levinthal 1989). Frost (2001) finds that the likelihood that a FS patent cites patents produced in the host-country, a proxy for R\&D local collaboration in his study, is positively associated with the innovation scale of the foreign firm. However, a problem with patent analyses is that they use citations of domestic patents as a proxy for local collaboration but do not measure the actual collaboration for innovation between FS and local partners. This methodological difficulty is overcome in studies based on the Community Innovation Surveys (CIS) of the EU or similar surveys, such as PITEC, the Spanish Innovation Survey used here, because these sources provide information on actual cooperation for innovation.

Some of these studies find a correlation between the nature of the FS's R\&D activities and its patterns of local cooperation for innovation (Álvarez and Cantwell 2011). Another study observes that manufacturing and service FS operating in Spain have greater propensity than domestic firms to cooperate for innovation in the domestic market, with the only exception being those subsidiaries with no internal R\&D expenditures (Holl and Rama 2014). The literature has termed as "dynamic learning FDI" the investment undertaken by an MNE in host countries that are relatively strong in a specific technology (Le Bas and Sierra 2002). Dynamic learning FDI includes two categories: i) technology seeking FDI aiming to offset home-country weaknesses and ii) home-base augmenting FDI targeting technologies in which both the MNE and the host country are relatively strong. FS that emphasise home-base exploiting strategies seem less likely to cooperate with local partners for innovation (Álvarez and Cantwell 2011; Holl and Rama 2014 ). The discussion suggests that innovation intensive FS are more likely to cooperate locally for innovation than non innovation intensive FS. The question left unanswered is whether innovation intensive FS are more likely to 
cooperate locally than innovation intensive domestic groups, and this questions is addressed here. Therefore, we formulate the following research questions.

RQ 1a: are FS more likely to cooperate locally for innovation than affiliated domestic firms?

$R Q 1 b:$ if yes, in which sectors?

RQ2 a: focussing more specifically on innovation intensive companies, are FS more likely to cooperate locally for innovation than affiliated domestic firms?

$R Q 2 b:$ if yes, in which sectors?

\subsection{Sectors}

The network and open innovation literature has argued that firms in high tech sectors are more prone to cooperate for innovation because they face more risky and costly innovation processes; therefore, the argument goes, cooperation may allow them to share costs and enter new technological fields (Miotti and Sachwald 2003). R\&D collaboration has been depicted as a kind of "elite sport" mainly practised by the world's largest firms from the high-tech industries (Bojanowski et al. 2012). This point of view is confirmed by the empirical literature (see, for instance, Carboni 2013; Ebersberger et al. 2011).

Little is known, however, regarding patterns of local collaboration for innovation of FS across sectors. The literature suggests that FDI is drawn to host-industries showing a large and dynamic demand, the presence of other global competitors also being an attractor. FDI in R\&D, more specifically, aims at tapping into local fields of expertise. Cantwell et al (2004) have shown that the sectors attracting US FDI in the UK have switched towards those fields that are British specialities. Similar results were found for Germany (Schmidt and Sofka 2009). Patent analysis suggests that two-way knowledge flows between FS and domestic firms are substantial, especially in developed countries, and that outflows are greater in sectors where the host-country displays stronger technological capabilities (Singh 2007). FS may have additional reasons for focusing on those host industries. According to a study, the MNE usually invests in host industries more or less similar to the "mother" industry, one of the reasons being the need to integrate local suppliers into its own technological culture, or at least those involved in design functions (Dyker 2004). The technological gap between the MNE and its local partners is likely to be smaller, in our view, in hostindustries enjoying Revealed Technological Advantages (hereafter, RTA). Other studies 
suggest, however, that FS operating in those industries are not necessarily more likely to collaborate with local partners. For instance, in a study on Spanish service and manufacturing firms, foreign status was negatively and significantly associated with R\&D collaboration with local universities in the food and drinks industry, and in the machine and equipment industry (Guimón and Salazar 2014). Following IB theory, we would have expected, instead, a positive association with foreign status, since these are industries in which Spain has RTA (Molero and García 2008). In our view, the possible association of local R\&D collaboration and foreign status may not depend exclusively on the RTA advantages displayed by a specific host-industry.

Some studies suggest that the behaviour of domestic firms may explain, at least in part, the presumed embeddedness of FS in some sectors of the host-country and not in others. In some countries, technologically leading domestic firms may be able to secure the most suitable local partners for R\&D collaboration and their strategies may, consequently, limit the access of FS to local partnerships (Álvarez and Cantwell 2011; Cantwell and Mudambi 2011). In this respect, the difficulties faced by FS may be especially pressing in-host industries that are at the technical forefront (Schmidt and Sofka 2009). Previous research implies that, in some host-industries, the strategies of FS might be only part of the picture, not the whole story. In our view, the cooperative strategies of FS across sectors should not be analysed in isolation.

As stated, we are especially interested in FS operating in sectors where technological change is rapid worldwide because these companies may be a vehicle for the international diffusion of state-of-the-art technology. Today, catching up processes may pose difficulties for countries that are not technology leaders, given the rapid rhythm of technology creation at the global scale. It is in those fast changing sectors that FS may have a role to play, given their privileged access to international sources of new technology. Consequently, we formulate the following research questions.

$R Q$ 3a: is the presence of cooperative FS greater in fast changing sectors than in slow changing sectors?

$R Q$ 3b: focusing more specifically on innovation intensive $F S$, is the presence of cooperative FS greater in fast changing sectors than in slow changing sectors?

\subsection{Networks of innovators}

Complex local networks involving FS and different types of local partners are likely to combine different types of knowledge. Faems et al (2005) argue that "it is not 
the number of collaboration agreements per se but rather the diversity of the firm's alliances that influences the innovative performance of the firm" (p. 240). Löof (2009), analysing MNEs in Sweden, concludes that R\&D collaboration takes place as a network phenomenon rather than as a one to one process. The network itself could be a locus of knowledge production (Bojanowski et al. 2012). Other studies find statistical complementarities between collaboration with universities and collaboration with other types of innovation partners (Carboni 2013; Srholec 2014). On the other hand, the diffusion of "soft" organisational innovation from the advanced countries to less developed countries is an important aspect of catching-up processes and MNEs may play a crucial role in this respect (Dyker 2004). Therefore, we formulate the following research questions.

$R Q$ 4a: is the presence of multi cooperative FS greater in fast changing sectors than in slow changing sectors?

$R Q 4 b$ : focusing more specifically on innovation intensive $F S$, is the presence of multi cooperative FS greater in fast changing sectors than in slow changing sectors?

Multi cooperative FS are defined below.

\section{METHODOLOGY.}

\subsection{Research context}

As in other intermediate countries, Spain shows structural imbalances between its general economic development and its technological position. More importantly for our purpose, the NIS also displays imbalances. Within the EU, an example of countries displaying such imbalances are those in the group of "moderate innovators" (e.g. Italy, Poland, Spain), which are characterized by an average innovation performance between $50 \%$ and $90 \%$ of the performance of the EU (European Commission 2013). Countries belonging to the group of "innovation leaders" (e.g. Denmark, Finland, Germany) combine a general high performance with a good one in most parameters; according to the European Commission, the most innovative countries have balanced NIS with strengths in all dimensions. In contrast, in the "moderate innovator" cluster, a much lower level of general performance is combined with significant structural disequilibria between different indicators. For instance, some relative strengths of Spain are in international scientific co- publications or in a substantial sales share of new innovations. At the same time, it displays low R\&D expenditures in the business sector and a limited presence of small and medium sized enterprises (SMEs) with product/process innovation. 


\subsection{Data and research strategy}

First, we use data on actual local cooperation for innovation obtained from the PITEC database, which provides anonymised micro-data for both domestic and foreign companies. PITEC is the Spanish Technological Innovation Panel collected by the Spanish Statistical Office (INE). The PITEC sample is representative of manufacturing firms located in Spain in 2004-2008. From this sample, around 1,965 companies have been selected, of which $35 \%$ are FS and $64 \%$ SFG, i.e. Spanish firms belonging to a group or affiliated domestic firms. It should be noted that non innovators are not included in our sample, as PITEC poses questions about cooperation for innovation only to firms defined by the questionnaire as "innovative", i.e. companies that have launched new products into the market, that have introduced new industrial processes, that have ongoing innovative activities or that have abandoned them during the two years prior to the survey. Other CIS-type surveys display the same feature (Ebersberger et al. 2011).

Secondly, this information is combined with patent data to identify highly dynamic sectors where technological evolution is particularly rapid worldwide. In doing so, we use a sector taxonomy based on patent analysis (Molero and García 2008). This taxonomy was selected for the following reasons. Being independent of any previous label placed on sectors, it provides a self-classification for any country, which can be then studied in the context of the international technological scenario. The taxonomy combines two axes to classify economic sectors: Relative (or Revealed) Technology Advantage (RTA) and global technological dynamism; their combination gives way to four types of cases. Each sector is classified according to a) its position in recent years in the world technological dynamism and b) its RTA. RTA is a relative, not an absolute value of the technological position of a national sector as compared to the average technological position of the country in the world scenario. Therefore, it indicates if a national sector performs better (advantage) or worse (disadvantage) than the world average for the country, as "revealed" by world patent data. Control for international technological dynamism is essential to assess proximity of the national industry to the worldwide evolution of technology. Most previous taxonomies classify sectors for all countries as belonging to the same categories, irrespective of the relative position of a specific country. The method used here, on the contrary, has the advantage of depending on the relative innovative performance of a country in a particular period of time. 
Our research strategy is as follow. Firstly, we perform a set of multivariate tests in order to explore RQ 1a, RQ 1b, RQ 2a and RQ 2b. See equation below:

$$
P\left(\text { domCoopInov }=1 \mid X_{i}^{T}, \beta^{T}, \alpha_{i}\right)=\Lambda\left(\alpha_{i}+\beta^{T} X_{i}^{T}\right)
$$

Secondly, we perform Bonferroni tests to investigate RQ 3a, RQ 3b, RQ 4a and RQ 4b. As stated, SFG are used as a control group in order to better understand the specificities of FS.

Appendix 1 shows the correlation matrix.

\subsection{Variables}

The variables used in our tests are presented below (for descriptions, see Appendix 2).

Local cooperation for innovation.

Cooperative activities are defined here as two separate organisations joining forces to share and develop knowledge in order to enhance their innovative performance. These arrangements do not include the acquisition of R\&D services via the market or via R\&D subcontracting. We use two different approaches to analyse local cooperation for innovation:

domCooplnnov. This is our dependent variable in the multivariate tests. It is a dummy variable, indicating whether the company has cooperated for innovation with external partners located in Spain in the last two years prior to the survey. "External" refers to partners external to the business group of the focal firm. The variable is similar to that analysed in most studies on cooperation for innovation (Holl and Rama 2014 ; Srholec 2014; Veugelers and Cassiman 2004).

Breadth. This variable indicates the breadth of local cooperative activities and has three possible responses: i) the firm has not cooperated for innovation with external local partners in the last two years; ii) it has cooperated with one type of local partner (for instance, universities) and iii) it has cooperated with at least two different types of local partners. We use Bonferroni tests to analyse this variable. Our purpose is to understand whether FS operating in fast changing sectors tend to be engaged in complex local R\&D networks (RQ 4a); again, we are especially interested in innovation intensive FS (RQ 4b). We define local R\&D networks that include at least two different types of local partners in addition to the focal firm, as complex (hereafter, referred to as complex networks).

Independent variable of interest 
Foreign ownership. This dummy variable indicates whether the company is an FS. The database distinguishes between two different categories of firms: unaffiliated companies and firms belonging to a group. Within the latter, information is provided about the location of the headquarters of the company. If they are located in a foreign country, the company is classified here as an FS. If not, the company is classified as an affiliated domestic firm, i.e. SFG. PITEC does not allow us to correctly identify native MNEs. The question deserves a brief digression since a study on Norway found that native MNEs had a greater positive impact than FS on the NIS (Ebersberger and Herstad 2012). Consequently, the comparison of FS and, specifically, native MNEs seems to be important. Nevertheless, in our view, the case of Norway cannot be extrapolated to the case of Spain. Firstly, the few Spanish MNEs are mostly in banking and other services; and in energy and water (not in manufacturing). Secondly, in accordance with the Uppsala school of thought, a large share of the Spanish FDI stock goes to culturally close countries, none of which are technological world leaders. For instance, in 2012, 30\% of total stock was invested in Latin America and, within the EU, Portugal was a major receiver country (Fernández-Otheo and Myro 2014). These circumstances limit the international flow of knowledge received by the Spanish manufacturing industry via native MNEs. Consequently, we do not feel that the abovementioned limitation of the PITEC data poses a serious problem in this case.

We compare FS to SFG or domestic affiliated companies, as this is a more symmetrical exercise, since all FS belong to a business group by definition. Most studies that compare FS and domestic firms recommend that the nature of the latter companies (affiliated or unaffiliated) be taken into account, since group membership seems to play an important role in cooperation for innovation (Ebersberger et al. 2011; Molero and Heijs 2002). Most unaffiliated Spanish firms are SMES, and many of these firms have clear difficulties establishing R\&D collaboration (Fernández-Esquinas and Ramos-Vielba 2011).

\section{Control variables}

Some of our control variables denote intensity as compared to their respective two-digit industry; for instance, above average size. For the calculation of averages, we used data for domestic firms (affiliated and unaffiliated) and FS. Intensity is indicated by an " $i$ " before the name of the variable. If we excluded unaffiliated domestic firms from the calculations we would be generating a bias in the definition of the features and capabilities of each industry, since our aim is to understand the FS' degree of embeddedness when characteristics of each industry are controlled for. 
i_size. This dummy variable indicates whether employment is above the twodigit industry average. Size of the industrial plant has been reported as a predictor of cooperation for innovation, and more specifically of local cooperation for innovation (see, for instance, Holl and Rama 2014; Miotti and Sachwald 2003). Size may reflect the absorptive capacity of the firm for benefiting from open innovation processes (Carboni 2013; López 2008).

i_export (intensity of exports as share of turnover, as compared to two-digit industry average). In a sample of service and manufacturing firms located in Spain, Holl and Rama (2014) found that exporters were more likely to be engaged in cooperation for innovation with either domestic or international partners.

i_RDpers_1 (number of employees involved in internal R\&D, as compared to the two-digit industry average). This dummy variable denotes whether the focal company, domestic or foreign, hires more R\&D personnel than the average company in its industry. Following Cohen and Levinthal (1989), the variable may indicate whether the focal firm enjoys more absorptive capacity than the average company in its twodigit industry -- a crucial consideration for a firm attempting to benefit from cooperation for innovation.

i_new (share of new or improved products in turnover compared to two-digit industry average). We start by calculating the sales of new to the firm innovations as a percentage of the focal firm's total turnover; then, we calculate whether this percentage is above that of the average company in the two-digit industry. Fernández Sastre (2012) found that, in Spain, companies engaged in local cooperation for innovation were more likely to launch new products into the market.

EU_market. Indicates whether the firm markets its products in the EU market.

Local_market. Indicates whether the firm markets its products in a Spanish regional market.

Variable used to calculate intensity

Two-digit industries. The database contains information on the two-digit industry in which the company operates. The Spanish CNAE (Clasificación Nacional de Actividades Económicas), similar to the NACE Rev classification in EU statistics, is used here to calculate whether the company is innovation intensive above the average level in its two-digit industry, i.e. i_innovExpend (definition below). We also use this variable to calculate $i \_s i z e, i \_$export, $i \_R D p e r s o n \_1$ and $i \_n e w$. This enables us to 
avoid size effects and other industry effects when we compare firms that operate in different industries.

Variables used to split the sample

i_innovExpend. While most previous analyses on cooperation for innovation analyse a single $R \& D$ variable, usually internal $R \& D$ expenditures at the company level, some studies suggest the need to approximate R\&D from a variety of angles (Ebersberger et al. 2011; Vega-Jurado et al. 2009). Furthermore, the Oslo Manual has conceptualised innovation as a process involving a range of factors (OECD/Statistical Office of the European Communities). Though important, internal R\&D is not the sole ingredient of innovative processes at the company level. Moreover, one of the strengths of the Spanish NIS is above EU-average share of new products, while one of its weaknesses is below-average business $R \& D$. A substantial part of the innovative process may be taking place outside of $R \& D$ departments. Therefore, we start by constructing an aggregated index that includes seven types of innovation expenditures (Appendix 2). We understand that a combined index is a better approach to the innovative capacity of firms than the consideration of just internal R\&D.

The selection of variables is in accordance with the criteria of the Oslo Manual to determine the scale of innovative activities. For each type of expenditure, we calculate a dummy variable indicating whether the innovation expenditures of the focal firm are above those of the average company in its two-digit industry. We then aggregate the seven dummy variables (one for each type of expenditure) and we calculate the two-digit industry average. Finally, we calculate a dummy variable (i_innovExpend) indicating whether the innovation expenditures of the focal firm are above those of the average company in its two-digit industry. For brevity, these companies are referred to here as advanced firms. In calculating averages, we take the full two-digit industry (not just the sample of FS and affiliated domestic firms) into account. Innovative non affiliated domestic firms also contribute to defining the average intensity of innovation at the industry level. A comprehensive approach is crucial to understanding the possible role of flows of knowledge coming through FS.

Sector. As stated, we use a taxonomy (Molero and García 2008) that combines two complementary indicators calculated through patent analysis: i) national technological advantages (RTA) and ii) worldwide speed of technological change. Combining both classifications, the above mentioned study arrives at four types of sectors: Dynamic Specialization (the sector is dynamic worldwide and Spain displays technological advantages); Lost Opportunities (the sector is dynamic worldwide but the 
host-country shows technological disadvantages); Stationary Specialization (the hostcountry shows technological advantages but the sector shows scarce technological dynamism worldwide), and Retreat, (the host-country has technological disadvantages and the sector displays poor technological dynamism worldwide). Each sector may include several two-digit industries (Table 1). Sectors characterized by rapid technological change are not necessarily high-tech sectors.

Our research strategy is an iterative approach, both for innovation intensity and taxonomy. We start with an overall estimation for all sectors and for all the firms (no distinction by taxonomy sector or innovation intensity). This estimation is replicated for a sub-sample of advanced firms; we use the $i$ innovExpend variable to split our sample into two sub-samples. The above mentioned estimations (full sample and advanced firms sub-sample) are repeated for the four sub-samples of firms segmented by sectoral taxonomy.

\section{Table 1}

\section{RESULTS.}

4.1. Descriptive statistics.

Table 2 shows descriptive statistics for FS and SFG. The share of FS that cooperate locally for innovation is larger than that of SFG. As compared to SFG, the shares of FS with above average size or above average propensity to export are larger. In contrast, SFG tend to be above the two-digit industry average concerning the four variables measuring technological level; more so than FS do.

\section{$\underline{\text { Table } 2}$}

We found a significant positive association between Foreign ownership and whether or not the company operates in sectors in which Spain has RTA (Table 3a). Nearly $70 \%$ of the sample FS operate in those sectors, i.e. Dynamic Specialization and Stationary Specialization (Table 3a). In contrast, there was no significant statistical association between Foreign ownership and whether or not the firm operates in fast changing sectors, i.e. Lost opportunity and Dynamic (Table 3b).

\section{Tables $3 \mathrm{a}$ and $3 \mathrm{~b}$}




\subsection{Multivariate tests: foreign status and domestic cooperation for}

innovation

Table $4 a$ displays five multivariate models that test for statistical associations between Foreign ownership and domCooplnnov, when above average size and other characteristics of firms are controlled for. Column 1 refers to all the sample firms and columns 2-5 to sub-samples of firms operating in each of our four taxonomy sectors (Dynamic, Stationary, Lost Opportunities and Retreat). For all firms, the coefficient of the independent variable of interest, Foreign ownership, is positive and statistically significant; therefore, foreign status and local cooperation for innovation are associated. The coefficient of Foreign ownership is also positive and significant in three of the four taxonomy sectors (columns 3, 4 and 5). An exception is the Dynamic sector (column 2), since, in this case, the coefficient of the Foreign ownership variable is not statistically significant; no association between foreign status and local collaboration for innovation was found. Apparently, FS operating in one of the two sectors characterized by rapid technological growth are not necessarily prone to engage in domestic cooperation for innovation. Note that this is also a sector in which the host country displays RTA (we return to this question below).

Next we explore whether Foreign ownership is associated with domCooplnnov in a sub-sample of advanced firms, both domestic and foreign (Table 4b). Column 1 displays a model for all advanced firms, independently of the taxonomy sector in which they operate. We now find that the coefficient of the independent variable of interest is not statistically significant; Foreign ownership and domCooplnnov are not associated. Looking at sectors (columns 2-5), we observe that the coefficient of Foreign ownership is positive for advanced firms operating in the Lost Opportunity sector (column 4) but now it is only tangentially significant (at $90 \%$ level). Again, the coefficient of Foreign ownership is not statistically significant in the Dynamic sector (column 2).

i_RDpers_ 1 displays a positive and statistically significant coefficient for all firms as well as for the four taxonomy sectors in the full sample (Table 4a) and in the subsample of advanced companies (Table 4b). With the exception of advanced firms operating in the Lost Opportunity sector, firms hiring more R\&D personnel than the average company in their respective two-digit industries are more likely to embark on local cooperation for innovation. The association of $i$ size and domCooplnnov is also positive and statistically significant in the full sample as well as in the sub-sample of advanced firms. 


\section{Tables $4 \mathrm{a}$ and $4 \mathrm{~b}$}

We replicate the models presented in Table $4 \mathrm{~b}$ with a more restrictive definition of advanced firms, which are characterised now as those companies with internal R\&D expenditure above the average in their respective two-digit industry. In doing so, we use $i$ intRDExpend to split our sample. When this limited definition of advanced firms is used, the coefficient for Foreign_ownership becomes positive and statistically significant for the full sample and for each of the taxonomy sectors; FS seem clearly more prone to cooperate with local partners than SFG. Our results suggest that analyses which only take into consideration internal R\&D expenditures (and omit other innovation expenditures) to define advanced firms may be optimistic concerning the contribution of FDI to the NIS of host-countries.

\subsection{Patterns of local cooperation for innovation across sectors}

Bonferroni tests are performed to identify statistically significant differences concerning cooperative strategies within the two groups of firms, FS and SFG (Table 5). Our aim is to understand whether FS engaged in fast changing sectors are significantly more prone to cooperate locally for innovation than FS engaged in slow changing sectors (RQ $3 a$ and RQ 3b). SFG are used as a control group. In addition, this "post hoc" test may help us to gain further insight into the results of the previous multivariate tests.

We start by cross tabulating domCoopInnov and Sector (Table 5). The results suggest that SFG operating in sectors with fast changing technology are particularly interested in cooperating locally for innovation, much more so than SFG operating in sectors with slow changing technology (significant results in bold fonts). In contrast, the share of FS that cooperate locally for innovation in each of the taxonomy sectors is quite similar. In our sample, cooperative FS oscillate between $29.8 \%$ of the FS in the Stationary sector and $33.4 \%$ of the FS in the Lost Opportunity sector but, according to Bonferroni tests, differences are not statistically significant. No preference for cooperation in fast changing sectors or for cooperation in sectors where Spain displays RTA was detected. We conclude that the distribution of cooperative FS tends to be even across sectors (Table 5, rows 1-3, columns 1-3). This result was confirmed for advanced FS. When we focus on the latter, we observe that the share of cooperative FS oscillates between $45.8 \%$ in the Retreat sector and $39.5 \%$ in the Stationary sector; again, differences across sectors are not statistically significant (Table 5, rows 1-3, 
columns 4-6). We conclude that the distribution of advanced FS is also even across taxonomy sectors.

In contrast, the share of cooperative SFG varies significantly across taxonomy sectors, oscillating between $25.1 \%$ in the Dynamic sector and $18.4 \%$ in the Retreat sector. This time, differences are statistically significant (Table 5 , row 5 , column 2 ). In the sub-sample of advanced SFG, the percentage of cooperative firms fluctuates between $24.6 \%$ in the Retreat sector and $33.5 \%$ in the Lost Opportunity sector; again, differences are statistically significant (Table 5, row 4, column 4). SFG that operate in sectors with fast technological change (Dynamic and Lost Opportunities) tend to look for local R\&D partnerships to a greater extent than SFG operating in a slow changing sector (Retreat).

\section{$\underline{\text { Table } 5}$}

We use the Bonferroni tests as "post hoc" tests that will help us to interpret the relationship between foreign status and local cooperation for innovation. According to the multivariate tests, the strength of the association between both variables is relatively greater in the Retreat sector, a slow changing sector in which Spain has no RTA (Table 4a, column 5 and Table 4b, column 5). This is precisely a sector in which, according to the "post hoc" tests, SFG display less interest in cooperation for innovation. Secondly, the association of foreign status and local cooperation for innovation is relatively weaker in the two fast changing sectors, Dynamic and Lost Opportunity. The Bonferroni tests suggest that SFG that operate in these sectors seem especially interested in cooperation for innovation. In our opinion, the parallel developments suggested by the multivariate tests and the Bonferroni tests are no coincidence. Note that FS show a similar interest in local cooperation for innovation across sectors, a finding confirmed for advanced FS.

As stated, we are especially interested in FS that are able to build complex networks of innovation in the host country. These firms are referred to here as multi cooperative FS. We attempt to assess whether their presence is greater in fast changing sectors than in slow changing sectors (RQ 4a); again, we more specifically focus on advanced FS (RQ 4b). We cross tabulate Breadth and Sector for, respectively, the sub-sample of FS and the sub-sample of SFG. We perform Bonferroni tests to assess whether the respective distribution of multi cooperative companies, domestic or foreign, is even across sectors (results available upon request). For FS, we find that Breadth and Sector are associated $\left(X^{2}=12.6923 ; \operatorname{Pr}=0.048\right.$; Cramer's $V=$ 0.0497). The share of multi cooperative SFG was higher in the Dynamic sector than in 
the Stationary sector, and differences were statistically significant $\left(X^{2}=-0120549 ; \operatorname{Pr}=\right.$ 0.012). In contrast, in the sub-sample of advanced FS, multi cooperative FS were evenly distributed across sectors. Breadth and Sector were not statistically associated $\left(X^{2}=9.4714 ; \operatorname{Pr}=0.149 ;\right.$ Cramer's V = 0.0693).

In the sub-sample of SFG, Breadth and Sector were significantly associated $\left(X^{2}\right.$ $=19.7030 ; \mathrm{Pr}=0.003 ;$ Cramer's $\mathrm{V}=0.0472$ ) and the distribution of multi cooperative SFG was uneven across sectors. Their presence was greater in the Dynamic sector than in the Retreat sector $\left(X^{2}=0.108133\right.$; $\left.\operatorname{Pr}=0.004\right)$ or the Stationary sector $\left(X^{2}=-\right.$ 080818; $\mathrm{Pr}=0.003$ ). Focussing on the sub-sample of advanced SFG, we observed that the variables were, again, significantly associated $\left(X^{2}=10.9402 ; \operatorname{Pr}=0.090\right.$; Cramer's $V=0.0526)$; the presence of multi cooperative SFG was significantly greater in the Lost Opportunity sector than in the Retreat sector $\left(X^{2}=14.9961 ; \operatorname{Pr}=0.045\right)$. To summarize, SFG tend to build complex networks in fast changing sectors rather than in slow changing sectors. This is not necessarily the case for FS.

\section{DISCUSSION}

In our sample, FS do not seem especially attracted by sectors with rapid technological change. This circumstance may limit the contribution of these firms to the diffusion of state-of-the-art technology in the host country. FS operate mainly in sectors in which the host country has RTA, i.e. Dynamic and Stationary. This is similar to findings for other European countries (Cantwell et al. 2004; Schmidt and Sofka 2009). The importance of Spain's technological advantages, together with the magnitude and depth of the domestic market, explain, in our view, the concentration of FS in those sectors. More specifically, the Stationary Specialization sector comprises a quite substantial number of so called traditional industries that have strongly attracted FDI. Interestingly, this does not imply that FS operating in those sectors are more likely than other FS to source local knowledge via cooperation for innovation.

FS are significantly more prone to be engaged in local cooperation for innovation than SFG, even when the size and other characteristics of companies are controlled for (RQ 1a). With an exception, results seem to support the idea that FS encourage cooperation for innovation in all the Spanish manufacturing industry (RQ $1 b)$. This is not unimportant in that Spanish firms in general do cooperate less than firms located in other European countries. In the case of Spain, we do not find a branch plant syndrome, in contrast to FS operating in comparable European countries (Ebersberger 
et al. 2011). This intriguing result supports the findings of Holl and Rama (2014) on service and manufacturing FS in Spain. An analysis of reasons for the specificity of Spain is clearly outside of the scope of this article. Such a study would have to include data for several countries. Nonetheless, we make a few preliminary arguments here. The reason offered by Holl and Rama (2014) for the greater embeddedness of FS as compared to their much more limited embeddedness in similar European countries was the substantial involvement of FS in production subcontracting networks in Spain; these arrangements, it was claimed, provided a framework for collaborations for innovation between contractors and local suppliers, reducing transaction costs. A study based on in-depth interviews with a small group of MNEs performing R\&D in Spain seems to confirm this opinion (Miravitlles et al 2013). The companies declared that the availability of qualified suppliers had been a key consideration for establishing their respective R\&D centres in the host country. Furthermore, early FDI policy often imposed the incorporation of a quite important percentage on local content on manufacturing FS. This circumstance, coupled with the rapid development of a nonnegligible domestic manufacturing network may have stimulated production subcontracting and, consequently, cooperation for innovation between FS and local suppliers. More recently, the Spanish innovation policy may have also played a role. In 2007, Spain was the OECD country that offered the most generous tax incentives to business R\&D (Guimón 2011). Spain was also the first country to use the European Technology Fund (2007-2013) in order to stimulate the R\&D activities of FS. Both explanations may be complementary. As noted by an UNCTAD (2005) report, specific government incentives are rarely effective in attracting FDI in R\&D when other conditions are not met in the host country.

Though FS seem more prone to cooperate locally for innovation than SFG, this is not necessarily specifically the case of "the best" FS. FS displaying newness of technology are not necessarily more prone to cooperate locally than similar SFG. FS operating in the Dynamic sector, a fast changing sector, were not more prone than their domestic counterparts to cooperate with local partners. This is a counter-intuitive finding since IB theory suggests that FS attempt to source local knowledge precisely from those sectors in which the host country is relatively strong, as is the case of the Dynamic sector. At least two possible explanations may help to account for our results. In this sector, FS may be absorbing local knowledge via methods not explored in our article. Secondly, FS operating in sectors in which the host country displays RTA may find some difficulties when attempting to launch local innovative networks, since technologically leading domestic firms may be able to secure the most suitable local 
partners for R\&D collaboration. Previous studies (Álvarez and Cantwell 2011; Cantwell and Mudambi 2011) validate this interpretation.

Also, advanced FS are not necessarily more likely than advanced SFG to engage in local collaboration for innovation (RQ 2a). In this subsample, moreover, Foreign ownership and domCooplnnov are not associated or are only weakly associated in fast changing sectors, i.e. Lost Opportunities and Dynamic Specialization sectors. In one of them (Dynamic Specialization), Spain shows technological advantages (Table 1). However, in the other (Lost Opportunities), Spain has technological disadvantages. In the face of fast technological change, a greater contribution of advanced FS to the upgrading of the latter sector would have been especially desirable since Lost Opportunities includes the electronics industries, which are essential to the development of modern economies and societies; and vehicles, one of the Spanish export industries. In contrast, the coefficient of Foreign ownership is positive and significant in slow changing sectors (Stationary and Retreat). Regarding advanced firms, the association between foreign status and domestic collaboration for innovation seems to be relatively stronger in those sectors (Table $3 b$, columns 3 and 5)(RQ 2b). FS are more embedded than SFG in sectors where their presence seems less useful for facilitating catching-up processes in Spain.

We now discuss results concerning the cooperative behaviour of FS operating in different taxonomy sectors. We attempted to understand whether the presence of cooperative FS was greater in fast changing sectors than in slow changing sectors and found that the cooperative behaviour of these companies was even across sectors (RQ 3a). Similar results were found for advanced FS (RQ 3b). Though the majority of FS seem to be attracted to sectors in which the host country has RTA, this does not imply that FS operating in those sectors are more likely than other FS to source local knowledge via cooperation for innovation. The stable cooperative behaviour of FS across sectors involving very different technologies suggests that these companies look for general capabilities in local partnerships, rather than for specific expertise in areas in which the host country has RTA. For instance, training with a focus on recruitment is actually an important driver of $R \& D$ collaboration between $F S$ and Spanish universities (Guimón and Salazar 2014). This confirms the idea that FS may expect a wide base of expertise from universities rather than immediate commercial applications in a specific industry (Cantwell 1995). This may contribute to explaining the stable presence of cooperative FS across sectors. The distribution of cooperative SFG is uneven across sectors and this is in contrast with the distribution of FS. SFG and particularly advanced SFG display a greater interest in cooperation in fast 
changing sectors than in slow changing sectors. In countries that are not technology leaders, SFG operating in fast changing sectors need to update their technology continuously in order to catch up, incurring in high R\&D costs. Our results are in line with those of a study on the linkages of Brazilian universities (do Couto e Silva Neto et al. 2013): the decision to cooperate locally may follow different motives in FS and in domestic firms.

The results of Bonferroni tests imply that some caution is necessary in attributing the results of the multivariate tests (Tables $3 a$ and $3 b$ ) to proactive strategies of FS. First, the "post hoc" tests suggest that the lack of association between Foreign ownership and domCoopInnov in the Dynamic sector (Tables $3 a$ and $3 b$, columns 2) may be explained by a greater interest in local cooperation for innovation on the part of SFG rather than by a lesser interest on the part of FS. As revealed now by the Bonferroni tests, patterns of local Cooperation for innovation among FS do not significantly vary across sectors. Secondly, Foreign ownership has the largest positive coefficient in the econometric models concerning the Retreat sector. However, this does not necessarily mean that FS in this sector are especially interested in local cooperation. Again, reasons may be sought in the behaviour of SFG operating in the Retreat sector, which seem relatively less interested in local cooperation for innovation as compared to SFG operating in sectors with fast technological change. In addition to these merely statistical considerations, another possibility is that FS find more difficulties in securing suitable partners in host industries endowed with RTA (Schmidt and Sofka 2009), as is the case of the Dynamic sector in Spain; the reason for this being that in those industries, domestic firms may recruit the best local partners. The literature has mostly assumed, without further study, that the statistical association between foreign status and local cooperation for innovation is an effect of the strategies of FS. Our results suggest, however, that these strategies are only part of the picture. "Post hoc" tests may help researchers to gain further insight into the results of multivariate tests; this is a methodological contribution of our article.

SFG (and advanced SFG) tend to build complex local networks in the two fast changing sectors, Dynamic and Lost Opportunities, rather than in the two slow changing sectors. FS prefer to build such networks in the Dynamic sector (as opposed to the Stationary sector) but results are not confirmed for advanced FS (RQ 4a). Therefore, we cannot provide a conclusive answer for RQ 4b.

\section{CONCLUSIONS}


We studied the association of foreign status and local cooperation for innovation in the Spanish manufacturing industry. We were especially interested in foreign subsidiaries that, in our view, could make a greater contribution to the technological upgrading of the host country owing to: intensity of innovation, newness of technology or ability to build complex local networks of innovators. The general comparison of FS with affiliated domestic firms shows the higher level of local cooperative activities of the former. However, when we focus on the foreign subsidiaries that are more likely to make a greater technological contribution to the host country, foreign status does not necessarily increase the probability of local cooperation for innovation. Although Spain has been successful in attracting cooperative foreign subsidiaries, our findings point to the need for more targeted policies that enable the host country to fully benefit from the internationalisation of R\&D. Linkage facilitation policies should focus, more specifically, on foreign subsidiaries well endowed with state of the art-technology, innovativeness or organization skills. The capacity of domestic affiliated firms, notably innovation intensive firms, to promote local cooperation for innovation is not far behind that of foreign investors. Moreover, domestic affiliated companies tend to cooperate locally and to even establish complex innovation networks in fast changing sectors more than in slow changing sectors. As argued by Erken and Gilsing (2005), the evaluation of the respective merits of domestic $R \& D$ and foreign $R \& D$ is an important avenue for future research.

In providing one of the infrequent case studies of an intermediate country, our article suggests that no general rules towards FDI in R\&D can be recommended, given the heterogeneity of situations. More specifically, concerning the policies of intermediate countries the capacity to discriminate across categories of sectors is essential. In sectors in which the host country enjoys technological know-how and a large domestic market (sometimes strengthened by a substantial presence of domestic exporters or investors in foreign markets), FDI in R\&D may contribute to deepening the internationalization of domestic firms. However, policies need to consider a balance between inward and outward spillovers. These are sectors in which the interaction between agencies in charge of attracting FDI and agencies in charge of promoting the internationalization of domestic companies has an important role to play. The situation is different in sectors where, in the face of rapid technological change, the host country is far-away from the technological frontier. In this case, FS are likely to display limited interest in cooperating with local innovators. Domestic technological upgrading needs to be fostered through development of local networks of highly qualified suppliers (here, the positive experience of Spain may be a reference), 
encouragement of clustering, and strengthening of education and R\&D institutions. These measures may contribute to expanding domestic resources as well as attracting high quality FDI. When the host-country is an export platform for the MNE, policies in these sectors need to stimulate high value-added contents through collaboration with local manufacturing suppliers and service firms. This is likely to promote innovative domestic SMEs and indirect exporters. The cases of, respectively, the Stationary Specialization and the Lost Opportunity sectors in Spain illustrate these two types of sectors. 
Table 1. Sectoral Typology

\begin{tabular}{|c|c|c|c|}
\hline & \multicolumn{2}{|c|}{ International Technological Dynamism } \\
\hline & & Slow & Fast \\
\hline \multirow[b]{2}{*}{ 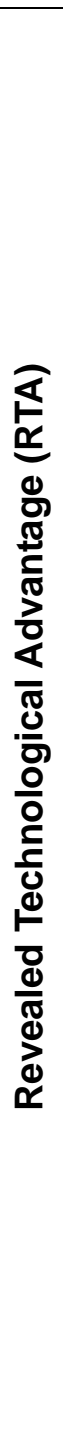 } & $\frac{\vec{\lambda}}{\hat{\alpha}}$ & $\begin{array}{l}\text { Stationary Specialization: } \\
\text { Food and drinks; paper products; } \\
\text { publishing, printing and reproduction; basic } \\
\text { chemical, pesticides and other agro- } \\
\text { chemicals, pharmaceutical, medicinal } \\
\text { chemical and botanic products; paints, } \\
\text { varnishes, printing ink and similar; soap, } \\
\text { detergents, cleaning and polishing; man- } \\
\text { made fiber, rubber and plastics; } \\
\text { manufacture of weapons and ammunition }\end{array}$ & $\begin{array}{l}\text { Dynamic Specialization: } \\
\text { Textile, wearing apparel; dressing; dyeing } \\
\text { of fur; basic metals; machinery for the } \\
\text { production and use of mechanical power } \\
\text { (except aircraft, vehicle and cycle } \\
\text { engines), agricultural machinery and other } \\
\text { purposes machinery; machine-tool; } \\
\text { domestic appliances; manufacture of } \\
\text { insulated wire and cable. }\end{array}$ \\
\hline & $\frac{\vec{v}}{\mathbb{a}}$ & $\begin{array}{l}\text { Retreat: } \\
\text { Tobacco; wood and cork products (except } \\
\text { furniture), straw and plaiting materials; non- } \\
\text { metallic mineral products; medical and } \\
\text { surgical equipment and orthopedic } \\
\text { appliances; instruments and appliances for } \\
\text { measuring, checking, testing, navigating } \\
\text { and other purposes (except industrial } \\
\text { process control equipment). }\end{array}$ & $\begin{array}{l}\text { Lost Opportunities: } \\
\text { Office machinery and computers; electric } \\
\text { motors, generators and transformers, } \\
\text { accumulators, primary cells and primary } \\
\text { batteries, lighting equipment and electric } \\
\text { lamps and electrical equipment; electronic } \\
\text { valves and tubes and other electronic } \\
\text { components and other electronic } \\
\text { components; television and radio } \\
\text { transmitters, apparatus for line telephony } \\
\text { and line telegraphy, television and radio } \\
\text { receivers, sound or video recording or } \\
\text { reproducing apparatus and associated } \\
\text { goods; optical instruments, photographic } \\
\text { equipment, watches and clocks; motor } \\
\text { vehicles, trailers and semi-trailers and } \\
\text { other transport equipment, fabricated } \\
\text { metal products, except machinery and } \\
\text { equipment, industrial process control } \\
\text { equipment; furniture; luggage. }\end{array}$ \\
\hline
\end{tabular}

Source: Adapted from Molero and García (2008)

Note. RTA $>1$ indicates sectors in which Spain has Revealed Technological Advantages.

RTA $<1$ indicates sectors in which Spain has no Revealed Technological Advantages 
Table 2. Descriptive statistics. Percentages (\%) of firms, by type of ownership

\begin{tabular}{|l|c|c|c|c|c|c|c|c|c|}
\hline & \multicolumn{9}{|c|}{ Variables } \\
\hline $\begin{array}{l}\text { Foreign } \\
\text { Ownership }\end{array}$ & domCoopInnov & i_size & i_new & i_export & i_RDpers & $\begin{array}{c}\text { i_int } \\
\text { RDExpend }\end{array}$ & i_innovExpend & EU_market & Local_market \\
\hline $\begin{array}{l}\text { Spanish Firms } \\
\text { belonging to a } \\
\text { group }\end{array}$ & 22.6 & 41.3 & 27.3 & 16.1 & 41.9 & 60.5 & 41.1 & 81.3 & 94.1 \\
\hline $\begin{array}{l}\text { Foreign } \\
\text { Subsidiaries }\end{array}$ & 31.3 & 58.5 & 23.3 & 20.5 & 40.9 & 56.7 & 36.3 & 92.5 & 89.4 \\
\hline Total & 25.7 & 47.5 & 25.8 & 17.7 & 41.5 & 59.1 & 39.4 & 85.3 & 92.4 \\
\hline
\end{tabular}

Notes: Definition of variables in Appendix 2.

domCoopInnov: Percentage of firms which cooperate locally for innovation

Other variables: Percentage of firms above the average in their respective two-digit industries. For instance, $i$ RDpers reports the percentage of firms with R\&D employment above the average firm in their respective two-digit industries. 
Table 3a. Cross tabulation of Foreign ownership and RTA (\% of firms)

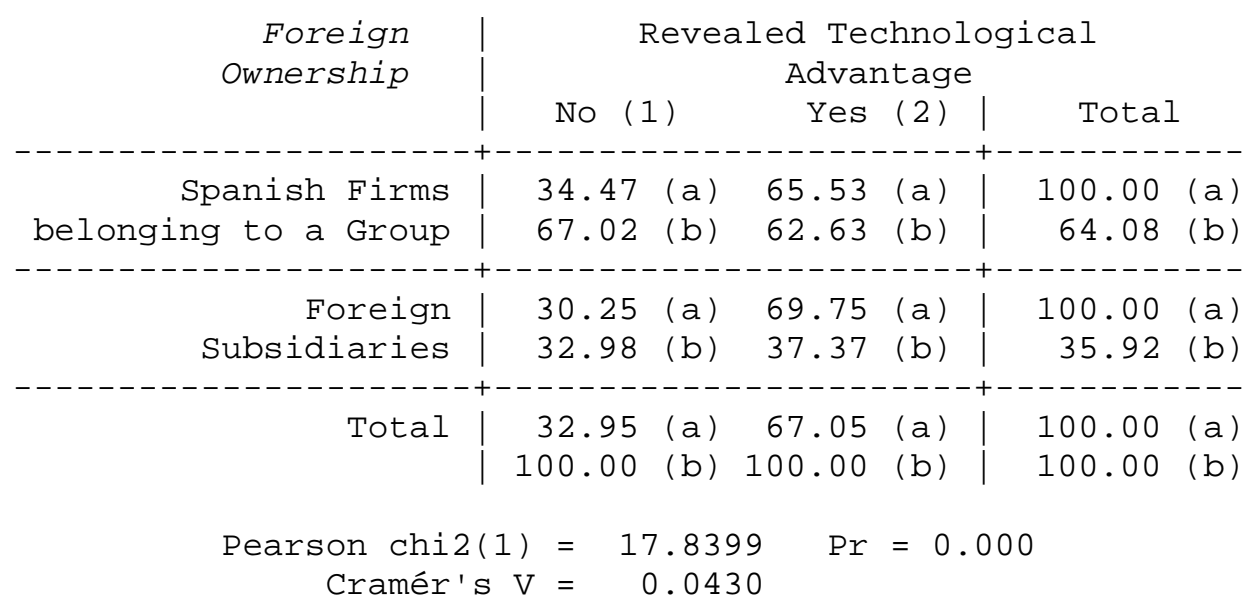

Table 3b. Cross tabulation of Foreign ownership and international technological dynamism (\% of firms)

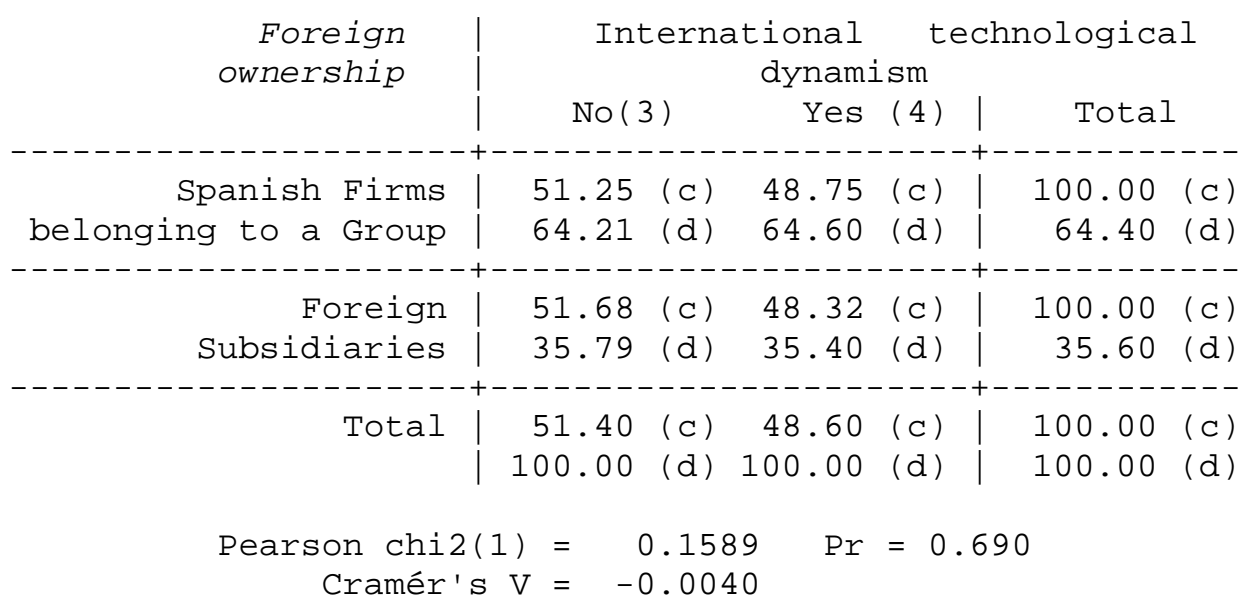

Notes:

(1) Includes Lost Opportunities and Retreat sectors.

(2) Includes Dynamic Specialization and Stationary Specialization sectors

(3) Includes Lost Opportunities and Dynamic Specialization sectors

(4) Includes Retreat and Stationary Specialization sectors

(a) Percentage of firms operating in sectors with or without RTA, by ownership

(b) Percentage of each type of ownership by sectors with or without RTA

(c) Percentage of firms operating in sectors displaying or not international technological dynamism

(d) Percentage of each type of ownership by sectors displaying or not international technological dynamism Foreign ownership and sector are defined in Appendix 2. RTA and international dynamism are defined in sub section 3.2 .

Source: Own elaboration based on PITEC data and Molero and García (2008) taxonomy. 
Table 4a. Logistic regression: Drivers of local Cooperation for innovation, by sector. All sample firms

\begin{tabular}{|c|c|c|c|c|c|}
\hline domCooplnnov & $\begin{array}{l}\text { All firms } \\
\text { (1) }\end{array}$ & $\begin{array}{l}\text { Dynamic } \\
\text { (2) }\end{array}$ & $\begin{array}{c}\text { Stationary } \\
\text { (3) }\end{array}$ & $\begin{array}{l}\text { Lost_Opportunities } \\
\qquad \text { (4) }\end{array}$ & $\begin{array}{l}\text { Retreat } \\
\text { (5) }\end{array}$ \\
\hline Foreign_ownership & $\begin{array}{l}0.6079163^{* \star \star} \\
(0.1719707)\end{array}$ & $\begin{array}{l}0.1286202 \\
(0.345373)\end{array}$ & $\begin{array}{l}0.5797879 * * \\
(0.2602688)\end{array}$ & $\begin{array}{l}0.8766468 \text { ** } \\
(0.3553419)\end{array}$ & $\begin{array}{l}1.458749 * * \\
(0.6246404)\end{array}$ \\
\hline i_size & $\begin{array}{l}0.7161015^{\star \star \star} \\
(0.1628764)\end{array}$ & $\begin{array}{l}0.9957868 * \star \star \\
(3247712)\end{array}$ & $\begin{array}{l}0.9282108 * * * \\
(0.261254)\end{array}$ & $\begin{array}{l}0.3252988 \\
(0.3351379)\end{array}$ & $\begin{array}{l}0.4949278 \\
(5079197)\end{array}$ \\
\hline i_export & $\begin{array}{l}-0.0646088 \\
(0.14455757)\end{array}$ & $\begin{array}{l}-0.0270932 \\
(0.2661661)\end{array}$ & $\begin{array}{l}-0.0077776 \\
(0.2427815)\end{array}$ & $\begin{array}{l}-0.0301668 \\
(0.2900723)\end{array}$ & $\begin{array}{l}-6041828 \\
(0.4904184)\end{array}$ \\
\hline i_RDpers_1 & $\begin{array}{l}0.9334996 * \star \star \\
(0.1403177)\end{array}$ & $\begin{array}{l}0.9353212 * * * \\
(02657852)\end{array}$ & $\begin{array}{l}1.102217^{* * *} \\
(0.2204845)\end{array}$ & $\begin{array}{l}0.5240373 \text { * } \\
(0.3134114)\end{array}$ & $\begin{array}{l}1.157084 \text { *** } \\
(4465613)\end{array}$ \\
\hline i_new & $\begin{array}{l}0.7054484 * * * \\
(0.1310478)\end{array}$ & $\begin{array}{l}0.3699716 \\
(0.2608829)\end{array}$ & $\begin{array}{l}0.7441382 * * * \\
(0.2125848)\end{array}$ & $\begin{array}{l}0.7800019 * \star \star \\
(0.2599997)\end{array}$ & $\begin{array}{l}1.096668 * * * \\
(0.4226999)\end{array}$ \\
\hline EU_market & $\begin{array}{l}0.8201276 \text { ***} \\
(0.2225317)\end{array}$ & $\begin{array}{l}1.527201 \text { *** } \\
(4584971)\end{array}$ & $\begin{array}{l}-0.2142137 \\
(0.347708)\end{array}$ & $\begin{array}{l}2.193419 * * \star \\
(0.5892285)\end{array}$ & $\begin{array}{l}1.27891 \text { ** } \\
(0.6115767)\end{array}$ \\
\hline Local_market & $\begin{array}{l}-0.5573181^{\star \star} \\
(0.2377583)\end{array}$ & $\begin{array}{l}-0.2482676 \\
(0.4287662)\end{array}$ & $\begin{array}{l}-0.9844191 * * \\
(0.438771)\end{array}$ & $\begin{array}{l}-0.1134344 \\
(0.7704611)\end{array}$ & $\begin{array}{l}-1.595363 \text { ** } \\
(0.7847822)\end{array}$ \\
\hline Number of observations & 7422 & 1921 & 988 & 1657 & 766 \\
\hline Wald Chi² & 148.77 & 43.86 & 41.98 & 37.35 & 26.71 \\
\hline Prob > Chi ${ }^{2}$ & 0.0000 & 0.0000 & 0.0000 & 0.0000 & 0.0004 \\
\hline
\end{tabular}

Notes: Standard errors in parentheses. ${ }^{* \star *},{ }^{* *},{ }^{*}=$ statistically significant at the 99,95 and $90 \%$ levels Description of variables in Appendix 2. Sectors in Table 1 and Appendix 2. 
Table 4b. Logistic regression: Drivers of local cooperation for innovation, by sector. Advanced firms

\begin{tabular}{|c|c|c|c|c|c|}
\hline domCooplnnov & $\begin{array}{l}\text { All firms } \\
\text { (1) }\end{array}$ & $\begin{array}{l}\text { Dynamic } \\
\text { (2) }\end{array}$ & $\begin{array}{c}\text { Stationary } \\
\text { (3) }\end{array}$ & $\begin{array}{l}\text { Lost Opportunities } \\
\qquad \text { (4) }\end{array}$ & $\begin{array}{l}\text { Retreat } \\
\text { (5) }\end{array}$ \\
\hline Foreign_ownership & $\begin{array}{l}0.1056535 \\
(0.1995306)\end{array}$ & $\begin{array}{l}0.4779007 \\
(0.4393946)\end{array}$ & $\begin{array}{l}0.9051644 \text { ** } \\
(0.4334043)\end{array}$ & $\begin{array}{l}0.8516883 \text { * } \\
(0.5002528)\end{array}$ & $\begin{array}{l}2.9979 * * \\
(1.095817)\end{array}$ \\
\hline i_size & $\begin{array}{l}0.5787808 * \star \star \\
(0.1917918\end{array}$ & $\begin{array}{l}1.15125^{\star \star \star} \\
(0.4217729)\end{array}$ & $\begin{array}{l}0.888766 \text { ** } \\
(0.4140887)\end{array}$ & $\begin{array}{l}-0.1659677 \\
(0.4765432)\end{array}$ & $\begin{array}{l}0.2049123 \\
(0.7908074)\end{array}$ \\
\hline i_export & $\begin{array}{l}-0.1967225 \\
(0.1692497)\end{array}$ & $\begin{array}{l}-04849642 \\
(0.3561278)\end{array}$ & $\begin{array}{l}-0.2620878 \\
(0.3855493)\end{array}$ & $\begin{array}{l}-0.3789608 \\
(0.4316385)\end{array}$ & $\begin{array}{l}-1.658811 \text { ** } \\
(0.7795469)\end{array}$ \\
\hline i_RDpers_1 & $\begin{array}{l}1.021067^{* * *} \\
(0.1692497)\end{array}$ & $\begin{array}{l}0.5998865 * \\
(0.3530195)\end{array}$ & $\begin{array}{l}1.663762 * * * \\
(0.3769949)\end{array}$ & $\begin{array}{l}-0.1619407 \\
(0.44255077)\end{array}$ & $\begin{array}{l}1.210559 \\
(0.7877121)\end{array}$ \\
\hline i_new & $\begin{array}{l}0.5716566 * \star \star \\
(0.1596513)\end{array}$ & $\begin{array}{l}0.1330825 \\
(0.3428876)\end{array}$ & $\begin{array}{l}0.5678728 \text { * } \\
(0.3438324)\end{array}$ & $\begin{array}{l}0.6354076 \text { * } \\
(0.3851655)\end{array}$ & $\begin{array}{l}1.30961 \text { * } \\
(0.7115788)\end{array}$ \\
\hline EU_market & $\begin{array}{l}0.6673502 \text { ** } \\
(0.2845821)\end{array}$ & $\begin{array}{l}0.56888439 \\
(0.5592812)\end{array}$ & $\begin{array}{l}-0.0281258 \\
(0.6244)\end{array}$ & $\begin{array}{l}2.374628 * * \\
(0.8757895)\end{array}$ & $\begin{array}{l}0.6750812 \\
(0.9315043)\end{array}$ \\
\hline Local_market & $\begin{array}{l}-0.4931969 * \\
(0.2805547)\end{array}$ & $\begin{array}{l}0.2505441 \\
(0.5876974)\end{array}$ & $\begin{array}{l}-1.775633 * \star \\
(0.851109)\end{array}$ & $\begin{array}{l}-0.4777679 \\
(0.6566776)\end{array}$ & $\begin{array}{l}-1.913357 \\
(1.183334)\end{array}$ \\
\hline Number of observations & 4867 & 953 & 1353 & 678 & 318 \\
\hline Wald Chi ${ }^{2}$ & 79.67 & 19.56 & 39.56 & 14.74 & 15.82 \\
\hline Prob > Chi ${ }^{2}$ & 0.0000 & 0.0066 & 0.0000 & 0.0395 & 0.0268 \\
\hline
\end{tabular}

Notes: Standard errors in parentheses. ${ }^{* \star *},{ }^{* \star},{ }^{*}=$ statistically significant at the 99,95 and $90 \%$ levels

Description of variables in Appendix 2. Sectors in Table 1 and Appendix 2. Advanced firms: i_innovExpend = 1 
Table 5. Bonferroni tests: differences in distribution of cooperative firms across sectors

\begin{tabular}{|c|c|c|c|c|c|c|}
\hline & \multicolumn{3}{|c|}{ Foreign subsidiaries (1) } & \multicolumn{3}{|c|}{ Advanced foreign subsidiaries (2) } \\
\hline & Lost Opp & Retreat & Dynamic & Lost Opp & Retreat & Dynamic \\
\hline Retreat & $\begin{array}{l}-0.001829 \\
1.000\end{array}$ & & & $\begin{array}{l}0.031976 \\
1.000\end{array}$ & & \\
\hline Dynamic & $\begin{array}{l}-0.017832 \\
1.000\end{array}$ & $\begin{array}{l}-0.016003 \\
1.000\end{array}$ & & $\begin{array}{l}-0.015457 \\
1.000\end{array}$ & $\begin{array}{l}-0.047427 \\
1.000\end{array}$ & \\
\hline Stationary & $\begin{array}{l}-0.035611 \\
0.458\end{array}$ & $\begin{array}{l}-0.33782 \\
1.000\end{array}$ & $\begin{array}{l}-0.07779 \\
1.000\end{array}$ & $\begin{array}{l}-0.030465 \\
1.000\end{array}$ & $\begin{array}{l}-0.062441 \\
1.000\end{array}$ & $\begin{array}{l}0.015015 \\
1.000\end{array}$ \\
\hline & \multicolumn{3}{|c|}{ Spanish firms belonging to a group (3) } & \multicolumn{3}{|c|}{$\begin{array}{l}\text { Advanced Spanish firms belonging to a } \\
\text { group (4) }\end{array}$} \\
\hline & Lost Opp & Retreat & Dynamic & Lost Opp & Retreat & Dynamic \\
\hline Retreat & $\begin{array}{l}-0.03971 \\
0.216\end{array}$ & & & $\begin{array}{l}-0.089665 \\
0.050\end{array}$ & & \\
\hline Dynamic & $\begin{array}{l}0.021751 \\
0.935\end{array}$ & $\begin{array}{l}0.061461 \\
0.005\end{array}$ & & $\begin{array}{l}-0.14411 \\
1.000\end{array}$ & $\begin{array}{l}0.75254 \\
0.117\end{array}$ & \\
\hline Stationary & $\begin{array}{l}-0.008846 \\
1.000\end{array}$ & $\begin{array}{l}0.030863 \\
0.459\end{array}$ & $\begin{array}{l}-0.030598 \\
0.135\end{array}$ & $\begin{array}{l}-0.041339 \\
0.573\end{array}$ & $\begin{array}{l}0.048326 \\
0.724\end{array}$ & $\begin{array}{l}-0.026928 \\
1.000\end{array}$ \\
\hline
\end{tabular}

Source: Own elaboration based on PITEC. Definitions of Sector, Foreign ownership and domCooplnnov in Appendix 2. Advanced firms: i_innovExpend $=1$

Results of cross tabulations of domCoopInnov and Sector: (1) Pearson $X^{2}=3.6443 ; \operatorname{Pr}=0.303 ;$ Cramer's V $=0.0324$.

(2) Pearson $X^{2}=1.5562 ; \operatorname{Pr}=0.669$; Cramer's V = 0.0352. (3) Pearson $X^{2}=12.0527$; Pr=0.007; Cramer's V $=0.0442$.

(4) Pearson $X^{2}=8.4206 ; \operatorname{Pr}=0.038 ;$ Cramer's V $=0.0576$.

Statistically significant differences are in bold fonts. 
Appendix 1. Correlation matrix

| Foreign ownership i_size i_export i_RDpers_1 i_new EU_market Local_market

\begin{tabular}{|c|c|c|c|c|c|c|}
\hline Foreign ownership & 1.0000 & & & & & \\
\hline i_size & | 0.1646 & 1.0000 & & & & \\
\hline i_export & | 0.0542 & 0.0586 & 1.0000 & & & \\
\hline i_RDpers_1 & | -0.0094 & 0.3160 & 0.0265 & 1.0000 & & \\
\hline i_new & | -0.0439 & -0.0110 & 0.0129 & 0.0936 & 1.0000 & \\
\hline EU_market & | 0.1526 & 0.1097 & 0.1768 & 0.0881 & 0.0140 & 1.0000 \\
\hline Local_market & | -0.0860 & -0.0227 & -0.0319 & -0.0061 & -0.0150 & 0.0578 \\
\hline
\end{tabular}


Appendix 2. Definition of variables.

\begin{tabular}{|c|c|c|}
\hline Name & Description & Values \\
\hline Foreign ownership & Dummy variable & $\begin{array}{l}1 \text { = FS (foreign subsidiary) } \\
0 \text { = SFG (Spanish firm belonging } \\
\text { to a group) }\end{array}$ \\
\hline Industry & CNAE classification of economic activities & $\begin{array}{l}26 \text { two-digit industries. } \\
\text { Calculations of averages include } \\
\text { domestic firms (affiliated or not) } \\
\text { and foreign subsidiaries }\end{array}$ \\
\hline i_size & $\mathrm{N}^{0}$. of employees & $\begin{array}{l}\text { Dummy variable taking } 1 \text { if the } \\
\text { firm's employment is above the } \\
\text { average company in its two-digit } \\
\text { industry }\end{array}$ \\
\hline i_export & $\begin{array}{l}\text { Exports, as \% of turnover, are above the two- } \\
\text { digit industry }\end{array}$ & $\mathrm{Y} / \mathrm{N}$ \\
\hline i_new & $\begin{array}{l}\text { New or improved products, as \% of turnover, } \\
\text { are above the two-digit industry }\end{array}$ & $\mathrm{Y} / \mathrm{N}$ \\
\hline $\begin{array}{l}\text { EU_market } \\
\text { Local_market }\end{array}$ & $\begin{array}{l}\text { - The company markets its products in the EU } \\
\text { market } \\
\text { - The company markets its products in a } \\
\text { Spanish regional market }\end{array}$ & $\begin{array}{l}\mathrm{Y} / \mathrm{N} \\
\mathrm{Y} / \mathrm{N}\end{array}$ \\
\hline Sector & Taxonomy sector & $\begin{array}{l}\text { Dynamic Specialization: the } \\
\text { sector is dynamic worldwide and } \\
\text { the host country displays } \\
\text { technological advantages } \\
\text { Lost Opportunities: the sector is } \\
\text { dynamic worldwide but the host- } \\
\text { country shows technological } \\
\text { disadvantages. Stationary } \\
\text { Specialization: the host-country } \\
\text { shows technological advantages } \\
\text { but the sector shows scarce } \\
\text { technological dynamism } \\
\text { worldwide. Retreat: the host- } \\
\text { country has technological } \\
\text { disadvantages and the sector } \\
\text { displays poor technological } \\
\text { dynamism worldwide }\end{array}$ \\
\hline \multicolumn{3}{|c|}{ Innovation related variables } \\
\hline i_RDpers_1 & No. of employees involved in internal R\&D & $\begin{array}{l}\text { Dummy variable taking } 1 \text { if the } \\
\text { firm is above the average } \\
\text { company in its two-digit industry }\end{array}$ \\
\hline i_int RDExpend & $\begin{array}{l}\text { Internal expenditures in R\&D, including personnel, } \\
\text { equipment, acquisition of software, etc. in previous year }\end{array}$ & $\begin{array}{l}\text { Dummy variable taking } 1 \text { if the } \\
\text { firm is above the average }\end{array}$ \\
\hline
\end{tabular}




\begin{tabular}{|c|c|c|}
\hline Name & Description & Values \\
\hline & (in €) & company in its two-digit industry \\
\hline External R\&D expenditures & $\begin{array}{l}\text { External expenditures in R\&D, including personnel, } \\
\text { equipment, acquisition of software, etc. in previous year } \\
\text { (in €) }\end{array}$ & $\begin{array}{l}\text { Dummy variable taking } 1 \text { if the } \\
\text { firm is above the average } \\
\text { company in its two-digit industry }\end{array}$ \\
\hline $\begin{array}{l}\text { External knowledge } \\
\text { acquisitions for innovation }\end{array}$ & $\begin{array}{l}\text { Expenditures with acquisitions of services and licences } \\
\text { related to the use of patents and to non patentable } \\
\text { technical knowledge (in } € \text { ) }\end{array}$ & $\begin{array}{l}\text { Dummy variable taking } 1 \text { if the } \\
\text { firm is above the average } \\
\text { company in its two-digit industry }\end{array}$ \\
\hline $\begin{array}{l}\text { Expenditures in technology } \\
\text { acquisition }\end{array}$ & $\begin{array}{l}\text { Expenditures in acquisition of machinery, equipment, } \\
\text { advanced hardware or software (in } € \text { ) }\end{array}$ & $\begin{array}{l}\text { Dummy variable taking } 1 \text { if the } \\
\text { firm is above the average } \\
\text { company in its two-digit industry }\end{array}$ \\
\hline Training expenditures & $\begin{array}{l}\text { Internal or external training of the workforce with the } \\
\text { specific aim of developing or introducing new or } \\
\text { significantly improved products or industrial processes } \\
\text { (in €) }\end{array}$ & $\begin{array}{l}\text { Dummy variable taking } 1 \text { if the } \\
\text { firm is above the average } \\
\text { company in its two-digit industry }\end{array}$ \\
\hline Innovation expenditures & $\begin{array}{l}\text { Introduction of new or significantly improved goods and } \\
\text { services into the market, including market research and } \\
\text { advertising (in } € \text { ) }\end{array}$ & $\begin{array}{l}\text { Dummy variable taking } 1 \text { if the } \\
\text { firm is above the average } \\
\text { company in its two-digit industry }\end{array}$ \\
\hline $\begin{array}{l}\text { Expenditures for preparing } \\
\text { and distributing innovations }\end{array}$ & $\begin{array}{l}\text { Design and other expenditures for producing and } \\
\text { distributing innovation that are not included in } R \& D \\
\text { expenditures (in } € \text { ) }\end{array}$ & $\begin{array}{l}\text { Dummy variable taking } 1 \text { if the } \\
\text { firm is above the average } \\
\text { company in its two-digit industry }\end{array}$ \\
\hline $\begin{array}{l}\text { Aggregate index of R\&D } \\
\text { intensity }\end{array}$ & $\begin{array}{l}\text { The } 7 \text { previous dummy variables are aggregated by } \\
\text { summing up the "Yes" responses. }\end{array}$ & $0-7$ \\
\hline i_innovExpend & $\begin{array}{l}\text { Dummy variable that indicates whether, concerning total } \\
\text { innovation expenditures, the focal company is above or } \\
\text { below average in its two digit industry }\end{array}$ & $\begin{array}{l}\text { 1= above industry average } \\
\text { (advanced firms) } \\
0 \text { =below industry average }\end{array}$ \\
\hline \multicolumn{3}{|c|}{ Cooperation variables } \\
\hline domCoopInnov & $\begin{array}{l}\text { Cooperated for innovation with external partners located } \\
\text { in Spain in the two years prior to survey }\end{array}$ & $\mathrm{Y} / \mathrm{N}$ \\
\hline Breadth & $\begin{array}{l}\text { Breadth of local cooperation for innovation with external } \\
\text { partners }\end{array}$ & $\begin{array}{l}0=\text { did not cooperate; } 1= \\
\text { cooperated with one type of } \\
\text { partner; } 2=\text { cooperated at least } \\
\text { with two types of partners }\end{array}$ \\
\hline
\end{tabular}




\section{References}

Alkemade, F., G. Heimeriks, A. Schoen, L. Villard, and P. Laurens (2015). "Tracking the Internationalization of Multinational Corporate Inventive Activity: National and Sectoral Characteristics." Research Policy .

Álvarez, I. and Cantwell, J. (2011), 'International integration and mandates of innovative subsidiaries in Spain', International Journal of Institutions and Economies, 3, 415-44.

Archibugi, A. and Petrobelli, C. (2003), 'The globalisation of technology and its implications for developing countries. Windows of opportunity or further burden?', Technological Forecasting and Social Change, 70, 861-83.

Bojanowski, M., Corten, R., and Westbrock, B. (2012), 'The structure and dynamics of the global network of inter-firm R\&D partnerships 1989-2002', Journal of Technology Transfer, DOI 10.1007/s1061-011-9234-7, 967-87.

Buckley, P. J., Clegg, J., and Wang, C.-F. (2007), 'Is the relationship between inward FDI and spillover effects linear? An empirical examination of the case of China', J Int Bus Stud, 38 (3), 447-59.

Cantwell, J. (1995), 'Innovation in a global world. Grobalisation does not kill the need for national policies"', The Dryden Press.

Cantwell, J. and Mudambi, R. (2011), 'Physical attraction and the geography of knowledge sourcing in multinational enterprises: ' Global Strategy Journal, 1 (3-4), 206-32.

Cantwell, J., Dunning, J., and Janne, O. (2004), 'Towards a technology-seeking explanation of U.S. direct investment in the United Kingdom', Journal of International Management, 10, 5-20.

Carboni, O.A. (2013), 'Heterogeneity in R\&D cooperation: an empirical investigation ', Structural Change and Economic Dynamics, 25, 48-59.

Cohen, W.M. and Levinthal, D.A. (1989), 'Innovation and learning: The two faces of R\&D', Economic Journal, 99, 569-96.

do Couto e Silva Neto, F. C., et al. (2013), 'Patterns of interaction between national and multinational corporations and Brazilian universities/public research institutes', Science and Public Policy, 40 (3), 281-92.

Dunning, J.H. and Lundan, S.M. (2009), 'The internationalization of corporate R\&D: A review of the evidence and some policy implications for home countries', Review of Policy Research, 26 (1-2), 13-34.

Dyker, D. A. (2004), 'Closing the productivity gap between Eastern and Western Europe: The role of foreign direct investment', Science and Public Policy, 31 (4), 279-87.

Ebersberger, B., S.J. Herstad, E. Iversen, E. Kirner, and O. Som (2011) 'Analysis of innovation drivers and barriers in support of better policies. Economic and market intelligence on innovation. Open innovation in Europe: effects, determinants and policy', (Oslo: European Commission. Enterprise and Industry).

Ebersberger, B. and Herstad, S.J. (2012), 'Go abroad or have strangers visit? On organizational search spaces and local linkages', Journal of Economic Geography, 12, 273-95.

Erken, H. and Gilsing, V. (2005), 'Relocation of R\&D - a Dutch perspective', Technovation, 25, 1079-92.

European Commission (2013), 'Innovation Union Scoreboard 2013', (Belgium), 76.

Faems, D., Van Looy, B., and Debackere, K. (2005), 'Interorganizational collaboration and innovation: towards a portfolio approach', Journal of Product Innovation Management, $22,238-50$.

Fernández-Esquinas, M. and Ramos-Vielba, I. (2011), 'Emerging forms of cross-sector collaboration in the Spanish innovation system', Science \& Public Policy (SPP), 38 (2), 135-46.

Fernández-Otheo, C.M. and Myro, R. (2014), 'La inversión de las empresas españolas en el exterior: patrón sectorial y espacial, y rentabilidad', in R. Myro and M.E. Álvarez López 
(eds.), España en la inversión directa internacional (Madrid: Instituto de Esudios Económicos), 245-96.

Fernández Sastre, J. (2012), 'Efectos y determinantes de la cooperación para la innovación tecnológica: Un estudio empírico sobre un panel de datos de empresas localizadas en España.', (Ph.D. Thesis, Universidad Autónoma de Madrid), Madrid.

Franco, E. and Quadros, R. (2003), 'Patterns of technological activities of transnational corporations affiliates in Brazil', Research Evaluation, 12 (2), 117-29.

Frost, T.S. (2001), 'The geographic sources of foreign subsidiaries' innovation', Strategic Management Journal, 22, 101-23.

Guimón, J. (2011), 'Policies to benefit from the globalization of corporate R\&D: An exploratory study for EU countries', Technovation, 31, 77-86.

Guimón, J. and Salazar, C. (2014), 'Collaboration in innovation between foreign subsidiaries and local universities: evidence from Spain', in CIRCLE (ed.), (Sweden: Lund University).

Holl, A. and Rama, R. (2014), 'Foreign subsidiaries and technology sourcing in Spain', Industry and Innovation, 21 (1), 43-64.

Knell, M. and Srholec, M. (2006), 'Innovation cooperation and foreign ownership in the Czech Republic', The Online Proceedings of The First Conference on Micro Evidence on Innovation and Development (MEIDE).

Le Bas, C. and Sierra, C. (2002), "Location versus home country advantages' in R\&D activities: some further results on multinationals' locational strategies', Research Policy, 31, 589609.

López, A. (2008), 'Determinants of R\&D cooperation: Evidence from Spanish manufacturing firms', International Journal of Industrial Organization, 26, 113-36.

Miotti, L. and Sachwald, F. (2003), 'Co-operative R\&D: why and whith whom? An integrated framework of analysis', Research Policy, 32, 1481-99.

Miravitlles, P., L. Guitart-Tarrés, F. Achcaoucaou, and A. Núñez-Carballosa. "The Role of the Environment in the Location of R\&D and Innovation Activities in Subsidiaries of Foreign Multinationals." Innovation: Management, Policy \& Practice 15, no. 2 (2013): 170-183.

Molero, J. and Heijs, J. (2002), 'Differences of innovative behaviour between national and foreign firms: measuring the impact of foreign firms on national innovation systems', Int.J.Entrepreneurship and Innovation Management, 2 (2/3), 122-45.

Molero, J. and García, A. (2008), 'The innovative activities of foreign subsidiaries in the Spanish Innovation System: An evaluation of their impact from a sectoral taxonomy approach', Technovation, 28, 739-57.

Phelps, N.A. (1993), 'Branch plant and the evolving spatial division of labour: a study of material linkage change in the Northern Region of England', Regional Studies, 27 (2), 87-101.

Rama, R. (2009), 'Foreign investment innovation. A review of selected policies ', The Journal of Technology Transfer, 33 (4), 353-63.

Schmidt, T. and Sofka, W. (2009), 'Liability of foreignness as a barrier to knowledge spillovers: Lost in translation?', Journal of International Management, 15 (4), 460-74.

Singh, J. (2007), 'Asymmetry of Knowledge Spillovers between MNCs and Host Country Firms', Journal of International Business Studies, 38 (5), 764-86.

Srholec, M. (2009), 'Does Foreign Ownership Facilitate Cooperation on Innovation? Firm-level Evidence from the Enlarged European Union ', European Journal of Development Research, 21, 47-62.

Srholec, M. (2014), 'Understanding the diversity of cooperation on innovation across countries: multilevel evidence from Europe', Economics of Innovation and New Technology, 24 (12), 159-82. 
UNCTAD (2005), 'World Investment Report 2005. Transnational corporations and the internationalization of R\&D', (New York and Geneva: United Nations), 331.

--- (2012), 'World Investment Report 2012. Towards a New Generation of Investment Policies', (New York and Geneva: United Nations), 204.

--- (ed.), (2001), World Investment Report 2001. Promoting Linkages (New York and Geneva: United Nations Conference on Trade and Development).

Vega-Jurado, J., Gutiérrez-Garcia, A., and Fernández-de-Lucio, I. (2009), 'Does external knowledge sourcing matter for innovation? Evidence from the Spanish manufacturing industry', Industrial and Corporate Change, 18 (4), 637-70.

Veugelers, R. and Cassiman, B. (2004), 'Foreign subsidiaries as a channel of international technology diffusion: Some direct firm level evidence from Belgium', European Economic Review, 48, 455-76. 